\title{
New Configurations and Techniques for Controlling Membrane Bioreactor (MBR) Fouling
}

\author{
Djamel Ghernaout ${ }^{1,2}$ \\ ${ }^{1}$ Chemical Engineering Department, College of Engineering, University of Ha'il, Ha'il, KSA \\ ${ }^{2}$ Chemical Engineering Department, Faculty of Engineering, University of Blida, Blida, Algeria \\ Email: djamel_andalus@hotmail.com
}

How to cite this paper: Ghernaout, D. (2020) New Configurations and Techniques for Controlling Membrane Bioreactor (MBR) Fouling. Open Access Library Journal, 7: e6579.

https://doi.org/10.4236/oalib.1106579

Received: July 4, 2020

Accepted: July 25, 2020

Published: July 28, 2020

Copyright $\odot 2020$ by author(s) and Open Access Library Inc.

This work is licensed under the Creative Commons Attribution International License (CC BY 4.0).

http://creativecommons.org/licenses/by/4.0/

\begin{abstract}
At the worldwide level, with numerous full-scale plants dealing with urban and industrial wastewater, the membrane bioreactor (MBR) process is viewed as a fully developed technique. Nevertheless, membrane fouling constitutes a critical barrier in the larger diffusion of MBR application. This work aims to discuss the new research and development progresses in the MBR technology in terms of fouling mitigation. New arrangements are examined to enhance the comprehension of the latest achievements in MBRs. Employed for biological fouling control, the quorum quenching technique is briefly introduced. As clean methods used for coping with membrane fouling, the ultrasonic technique and the surface grafting methods are also suggested. Several ameliorations focused on the module arrangement, aeration procedures, control setups, surface amendments, low-energy membrane cleaning techniques, or new fouling mitigation procedures, for instance, mechanical cleaning with granular medium, membrane vibration, or electric field. Between such ameliorations, hybrid setups, merging MBR with different techniques, employing prospects of the diverse methods to get the better of regular limitations of the MBRs are the most convenient. Nonetheless, implementing such novel fouling alleviation procedures for large scale MBRs needs more study. Sustainable control of membrane fouling necessitates utilizing more than one single strategy. Even with unceasing enhancements and expansions, fouling control features remain to be fully met.
\end{abstract}

\section{Subject Areas}

Chemical Engineering \& Technology

\section{Keywords}

Membrane Bioreactor (MBR), Membrane Fouling, Quorum Quenching 
(QQ), Quorum Sensing (QS), Activated Sludge (AS), Extracellular Polymeric Substances (EPSs)

\section{Introduction}

Through the world, the membrane bioreactor (MBR) process is adopted as a firmly proved, fully developed technique with numerous full-scale plants dealing with both municipal and industrial wastewater [1] [2]. Nevertheless, some drawbacks avert the larger acceptation of such a technique, such as a membrane fouling and energy consumption [3] [4]. This is why huge research and development (R \& D) attempts remain taken [5]. Such R \& D endeavors have conducted to an augmentation in the number of reports during the last two years.

Several recent discussions concentrated on features, like fouling characterization, visualization and foulants identification [6] [7] [8], modeling [9] [10] [11] [12] [13], membrane cleaning [14] [15], introduction of activated carbon [16], fouling control [17] [18], process monitoring [19], osmotic MBRs [20] [21] [22], removal of pharmaceutical compounds [23] [24] [25] and treatment of industrial wastewaters [26] [27]. As a consequence, it is required to summarize methodically such novel expansions in MBR technology.

This work aims to discuss the new R \& D progresses in MBR technology as for fouling mitigation, both being the fundamental dares and significant features of MBR application. New arrangements are examined to enhance the comprehension of the latest achievements in MBRs. Employed for biological fouling (biofouling) control, the quorum quenching (QQ) technique is briefly introduced. As a clean method used for coping with membrane fouling, the ultrasonic technique is shortly discussed. Finally, surface grafting techniques for dealing with membrane fouling are also suggested.

\section{Membrane Fouling Control}

Even if MBRs are presently a fully developed technique, membrane fouling stays the most significant running issue, retarding their general and wide-scale implementation [28] [29]. Membrane fouling decreases MBR productivity, augments the energy demands because of air-scouring, and needs recurrent cleaning of the membrane to reinstate its permeability [30] [31]. Repeated membrane cleaning, however, reduces the membrane's life-time and leads to bigger membrane replacement prices. Therefore, numerous reports have been dedicated to membrane fouling, with a view to interpreting the pathways in charge of its generation and to suggest strategies to relieve this [1] [32] [33].

In MBRs, fouling is generated from the interaction between the mixed liquor and the membrane [1]. There are three major pathways in charge of membrane fouling: 1) pore narrowing which is related to the sorption of dissolved 
and micro-colloidal substances possessing a size much smaller than the membrane pore size, 2) pore plugging because of the deposition of solids possessing a size similar than to that membrane pores and 3) cake layer production on the membrane's surface because of the deposition of matters on the membrane's surface [34]. There are several kinds of foulant: biofilm comprising extracellular polymeric substances (EPSs), soluble organics, particulates, colloids, dissolved inorganic compounds [8] [35] [36]. Numerous factors could influence membrane fouling in MBR techniques: 1) the membrane features, 2) the mixed liquor characteristics, 3) the running circumstances and, 4) the wastewater features.

Dominating and reducing membrane fouling remains crucial in MBR technology to guarantee a cost-effective and long-term process [37]. Six important procedures are implemented to dominate membrane fouling [38]: 1) implementation of appropriate pre-treatment to the feed wastewater, 2) permeate backflushing/backwashing or relaxation, 3) chemical cleaning of membranes, 4) chemically improved backwash, 5) membrane scouring through coarse bubble aeration and, 6) chemically modifying the mixed liquor [1] [39] [40].

In backflushing, the filtration flow is reversed to eliminate the solids fixed to the membrane surface. In relaxation, the filtration operation is paused to alleviate the membrane from the formed pressure. Backflushing or relaxation is merged inside the standard working of the MBR; thus, a filtration cycle is composed of a few minutes of filtration pursued by a short backflushing or relaxation time. Backflushing/relaxation could eliminate most of the reversible fouling and is, therefore, performant in eliminating the cake layer. In a submerged MBR, the needed membrane scouring is performed via coarse bubble aeration that is realized at the bottom part of the membrane modules [41] [42]. Regulating the implementation of the coarse bubble aeration could be realized in terms of intensity and duration, with intermitted aeration also being used. Chemical cleaning can be performed via injecting mineral organic acids, caustic soda, or sodium hypochlorite. Sodium hypochlorite is frequently added to eliminate biofouling and citric acid is injected to eliminate inorganic fouling. Chemical cleaning could also be realized throughout the usual MBR running via injecting a low chemical level to the backflush water; such an operation is famous as chemically enhanced backflush. Chemical cleaning is very efficacious in dealing with irremovable fouling, which could not be reduced throughout the usual running of the MBR. Nevertheless, recurrent, intensive chemical cleaning decreases the life of the membrane [1].

Additives could be injected into the biomass with a view to change the mixed liquor properties, improving the filtration technique, and decreasing fouling. Such additives could be coagulants, polyelectrolytes, adsorbing agents, and membrane performance enhancers. Coagulants add positive ions, neutralizing the negative charges of biomass, therefore improving flocculation [43]. Adsorbents could be zeolite and activated carbon. Such products could be inserted into the mixed liquor of MBR to alleviate fouling through adsorbing colloidal and 
dissolved matters [44] [45]. A natural zeolite was added to reduce the level of dissolved microbial products and so alleviate fouling [46]. An added sponge has the potential to decrease cake generation and pore blockage in a submerged MBR [47]. Injecting $1 \mathrm{~g} / \mathrm{L}$ of powdered activated carbon reduced the specific resistance of the cake film that developed on the membrane's surface [48]. Introducing diverse additives has shown that the cationic polymer MPE50 and poly-aluminum chloride are so efficacious in reducing membrane fouling [48]. Nevertheless, inserting additives is not commonly utilized in full-scale MBRs because it is unknown if the price of chemical usage is approved by the membrane fouling reduction. In addition, the long term consequences of utilizing, or avoiding utilizing, additives have not been investigated in detail [1].

Modifying chemically the membrane's surface is considered as a new technique that can be implemented to ameliorate MBR efficiency. Indeed, a fresh antifouling coating is applied to commercial UF membranes, which was based on a polymerizable bicontinuous microemulsion technique [49]. These scientists [49] juxtaposed the efficacy of a fresh MBR in which such a coating was implemented to a traditional MBR and proved that the fresh MBR illustrated much lower fouling. Likewise, researchers [50] suggested a composite microfiltration membrane, which was fabricated via blending polyvinylidene fluoride (PVDF) and hydrophilic graphene oxide (GO) nanosheets. Such a PVDF/GO membrane was tried on an MBR setup and worked better as it depicted higher critical flux, lower cleaning frequency, and lower membrane resistance than a classical PVDF membrane of an MBR. Lately, quorum quenching (QQ) has been recognized as an efficient antifouling procedure [51]. Nevertheless, there are so restricted full-scale implementations and feasible problems like the cost and stability of enzymes have to be resolved [1] [52]. More details about QQ are given in Section 4.

Merging advanced oxidation processes [53] or electrocoagulation [54] with MBRs could be extremely performant in eliminating recalcitrant compounds like pharmaceuticals and reducing MBR fouling [55] [56]. Moreover, combining microbial fuel cells with MBRs (MFC-MBR) to remedy wastewater could as well reduce membrane fouling. Decreasing membrane fouling is affected to a modification in the activated sludge (AS) features because the biomass in the MFC-MBR technique is categorized by a lower quantity of loosely bound EPS, more homogenized sludge and a lower quantity of filamentous bacteria [57]. Nevertheless, in the MFC-MBR technique, the major reason for its utilization is not the decrease of membrane fouling but targets like an ameliorated reduction of organic micropollutants, energy recovery, and lower operating expenses. Further, these merged techniques stay in their premature step of expansion since they are being examined at the bench and pilot-scale levels [1] [58].

\section{New Configurations for Dealing with Membrane Fouling}

In terms of new configurations in the field of MBRs, fresh $\mathrm{R} \& \mathrm{D}$ progress con- 
centrated mainly on membrane fouling control [1] [59]. Recently, several MBR setups employing dynamic shear-enhanced filtration through rotation, vibration, or reciprocation movement have been assessed to decrease membrane fouling [60]. Rotating MBRs have been furnished with flat-sheet [61] [62] [63], tubular [64], hollow fiber [65], or helical [66] membrane modules. Elevating rotation speed could conduct to better effectiveness in terms of fouling control [62]. Scientists [61] observed that rotation speed has an effect on cleaning effectiveness until a critical speed of $60 \mathrm{r} / \mathrm{min}$ was attained, after which little impact is detected. Researchers [63] proved that rotating flat-sheet MBR has a slower fouling rate juxtaposed to traditional MBRs when consuming the identical energy. Other scientists [1] evaluated via modeling investigations that the rotation efficacy in terms of fouling prevention was $12 \%$, proposing that prevention of cake build-up and fouling is mainly realized by air-scouring. Presently, numerous kinds of rotation MBRs are at hand on the MBR market as commercial products, comprising a cross-flow MBR system with rotating ceramic discs impellers Grundfos BioBooster [67] and Huber vacuum rotation membrane VRM ${ }^{\circledast}$ bioreactor [68]. In vibrating MBR (VMBR), different motions/mechanical forces (i.e., longitudinally, transversely, torsionally, or their combination) produce sheer at the membrane's surface to alleviate fouling [60]. As a fouling control solution, numerous VMBRs have been investigated like transverse vibration system [69], vertical movement [70], magnetically induced membrane vibration (MMV-MBR) [71], and high-frequency powerful vibration (HFPV-MBR) [1]. Such configurations permit a low air-scouring procedure thanks to the cyclic application of vibration. Further, they possess a capacity to lower dissolved oxygen (DO) in the AS returned from the membrane tank to the anoxic tank, which is frequently DO-rich and decreases the MBR denitrification performance [72]. Low frequency and low amplitude vertical vibrations were enough to conserve the hollow-fiber membrane practically free from fouling [73]. Critical fluxes of a bench-scale unit augmented from 15 to $27 \mathrm{~L} / \mathrm{m}^{2} \mathrm{~h}$ when membrane vibration was used, and further to $56 \mathrm{~L} / \mathrm{m}^{2} \mathrm{~h}$ when frequency of vibrations augmented from 1.7 to $8.4 \mathrm{~Hz}$ [74]. Further, more scientists [69] [70] noted a decreased fouling rate and improved critical flux throughout vibration enhanced filtration. Moreover, researchers [70] noted that $1 \%-2 \%$ loosening of fibers could further augment the permeate flux. Scientists [71] established that MMV-MBR attained higher flux and lower levels of fouling juxtaposed to aerated setups. In the HFPV-MBR, periodic high-frequency vibrations until $223 \mathrm{~Hz}$ were applied throughout the relaxation of hollow fiber membranes, without stopping the work of the submerged MBR setup [1]. Then, membrane effectiveness in respect to TMP and flux were recuperated to the circumstances of an almost clean membrane [1]. Even if numerous VMBRs look so encouraging, several vibration systems were only tested at a small scale and at low MLSS levels of $4-5 \mathrm{~g} / \mathrm{L}$. Researchers [15] discussed the vibration/rotation MBRs data. The reciprocation $\mathrm{MBR}$ (rMBR) uses inertial force on the membrane fibers via the horizontal reciprocating motion of the 
membrane cassette to decrease membrane fouling in the lack of air scouring [72]. The rMBR avoids the necessity of air-scouring setup and increased DO level in the return AS stream to the anoxic tank decreasing denitrification efficacy [1] [75].

The recently developed helical membrane modules boost scouring, decrease membrane fouling, and augment permeate flux thanks to vortex mixing and related intensified turbulence at the membrane surface [76] [77]. In the premature devices, the module was put vertically with a lower part loose; while in a more modern version, the module rotated counterclockwise to more elevate permeate flux by $27 \%$ [66]. In the Pentair's Helix membranes a helically-winding ridge, made of the same material as the membrane, is located on the inside of the membrane [78].

In baffled MBR (BMBR), incorporated baffles separate the bioreactor into two areas [1]. Such a division aims to alternatively generate anoxic/aerobic circumstances in the tank provided that wastewater is fed in a suitable manner [79]. Such circumstances are anticipated to catalyze concurrent nitrification and denitrification, leading to performant nitrogen elimination [80]. Throughout pilot-scale trials, the average reduction performances of total organic carbon (TOC), total phosphorous (TP), and total nitrogenous (TN) were $85 \%, 97 \%$, and $77 \%$, respectively [80]. In addition, because of the gap in a gas hold-up and fluid density in various areas, throughout aeration a cross-flow over membrane surface is generated furnishing bonus membrane cleaning [81]. As an illustration, scientists [82] suggested an airlift oxidation ditch membrane bioreactor (AOXMBR) including a submerged flat-sheet membrane and air injection setup put between two baffles furnishing aeration for biological targets, membrane scouring and AS circulation. Lately, employing baffles, incorporated in the membrane compartment of a submerged MBR, was tested to regulate hydraulic circumstances in the device with a view to ameliorating aeration effectiveness [81] and to improve the performance of mechanical cleaning with granules [83]. Table 1 gives a global view of new MBR configurations for enhanced membrane fouling control [1].

\section{Quorum Quenching (QQ) Technique for Biofouling Control}

In the MBRs technology, biofouling is described as the undesirable aggregation of microorganisms on the membrane surface [51] [85] [86]. Even if it has been largely investigated during the last twenty years, it stays a crucial restricting factor to the larger MBR implementation for treating wastewater (Table 2) [86] [87]. Two decades ago, the idea of quorum sensing (QS)/quorum quenching (QQ) was suggested as an anti-fouling procedure for MBRs [88] (Figure 1). Several investigations have established the capacity of QQ for biofouling control in MBR via diverse means [89]. The progression of QQ-MBR has progressed in terms of QQ-microorganisms, QQ-media, and the size of the QQ-MBRs tried. Oh and Lee [51] focused on the QS/QQ researches concerning the explanation 
Table 1. General view of fresh MBR configurations for enhanced membrane fouling control [1].

\begin{tabular}{|c|c|c|c|}
\hline MBR type & Membrane type & Main results in matter of fouling & Reference \\
\hline Rotating MBR & Flat sheet & $\begin{array}{l}\text { Flux augmented from } 42 \mathrm{~L} / \mathrm{m}^{2} \mathrm{~h} \\
\text { to } 47 \mathrm{~L} / \mathrm{m}^{2} \mathrm{~h} \text { when rotational } \\
\text { speed elevated from } 15 \text { to } 25 \mathrm{r} / \mathrm{min}\end{array}$ & [84] \\
\hline Rotating MBR & Flat sheet & $\begin{array}{l}\text { Membrane fouling rate is much lower } \\
\text { in rotating MBR juxtaposed to } \\
\text { traditional MBR for the identical } \\
\text { energy consumption }\end{array}$ & [64] \\
\hline Rotating MBR & Tubular & $\begin{array}{l}\text { The fouling rate decreased } \\
\text { as the rotational speed of } \\
\text { the module increased }\end{array}$ & [65] \\
\hline Rotating MBR & Hollow fiber & $\begin{array}{l}\text { At the tested rotational frequencies, } \\
\text { high dispersive conditions were } \\
\text { present and significantly larger than } \\
\text { those observed during static operation }\end{array}$ & [66] \\
\hline Reciprocal MBR & Hollow fiber & $\begin{array}{c}\text { Low and stable transmembrane } \\
\text { pressure was achieved at } 40 \mathrm{~L} / \mathrm{m}^{2} \mathrm{~h} \\
\text { by use of repetitive } \\
\text { membrane reciprocation }\end{array}$ & [67] \\
\hline Helical membrane & Filter cloth sheet & $\begin{array}{l}27 \% \text { enhancement of stable flux can } \\
\text { be maintained by rotating a } 360^{\circ} \\
\text { helical membrane, compared to } \\
\text { a rotating same sized flat membrane, } \\
\text { at a rotating speed of } 160 \mathrm{rpm}\end{array}$ & [1] \\
\hline Baffled MBR & Flat sheet & $\begin{array}{l}10 \%-30 \% \text { increase in membrane } \\
\text { surface shear compared with } \\
\text { the no-baffle configuration } \\
\text { at the same aeration intensity }\end{array}$ & [71] \\
\hline
\end{tabular}

Table 2. Category of fouling in membrane following foulant category [87].

\begin{tabular}{|c|c|c|}
\hline Type & Description & Foulants \\
\hline $\begin{array}{l}\text { Colloidal } \\
\text { Fouling }\end{array}$ & $\begin{array}{l}\text { Accumulation of particles on } \\
\text { membrane surface and inside } \\
\text { membrane pores, forming a cake layer }\end{array}$ & $\begin{array}{l}\text { Suspended solids and particles } \\
\text { such as silicate, ferric oxide, } \\
\text { iron oxide and aluminum oxide }\end{array}$ \\
\hline $\begin{array}{l}\text { Inorganic } \\
\text { Fouling }\end{array}$ & $\begin{array}{l}\text { Precipitation deposits resulting in } \\
\text { bulk and membrane crystallization }\end{array}$ & $\begin{array}{l}\text { Inorganic salt such as calcium } \\
\text { carbonate, calcium sulfate, calcium } \\
\text { phosphate and sodium chloride }\end{array}$ \\
\hline $\begin{array}{l}\text { Organic } \\
\text { Fouling }\end{array}$ & $\begin{array}{l}\text { Adsorption of natural organic } \\
\text { compounds on membrane, } \\
\text { caused gel formation }\end{array}$ & $\begin{array}{l}\text { Natural organic matter such as } \\
\text { fulvic acid, protein, polysaccharides } \\
\text { and polyacrylic polymer }\end{array}$ \\
\hline Biofouling & $\begin{array}{l}\text { Formation of biofilm } \\
\text { on membrane surface }\end{array}$ & $\begin{array}{l}\text { Aquatic organism such as } \\
\text { fungi, algae and bacteria }\end{array}$ \\
\hline
\end{tabular}

and control of biofouling in MBRs, comprising the determination of QS signals, the isolation of QS signal forming or decomposing microbes, and different practical 


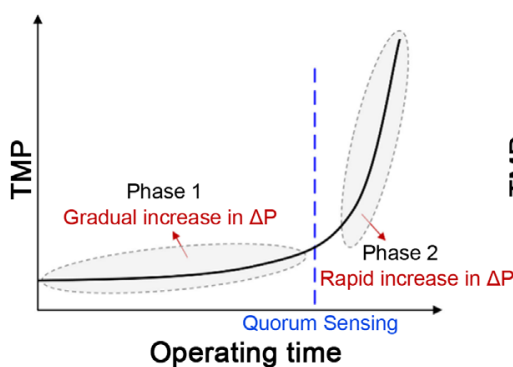

(a)

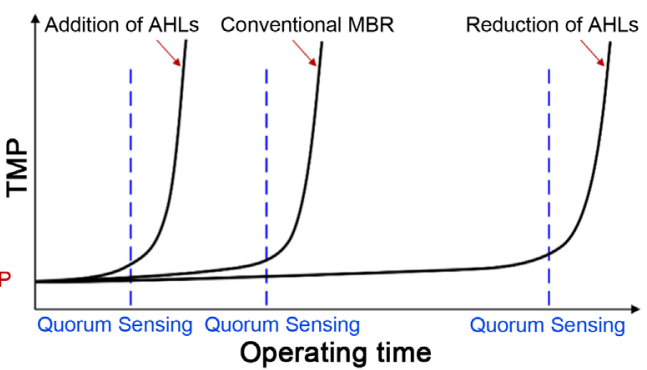

(b)

Figure 1. (a) Typical profile of trans-membrane pressure (TMP) increase during operation of MBRs for wastewater treatment, and (b) change in the point of quorum sensing (QS) and TMP increase as a function of the concentration of $N$-acyl homoserine lactone (AHL) signal molecules [51].

procedures to implement enzymatic or bacterial QQ in the form of QQ-media to alleviate membrane biofouling. They reviewed the dares facingsuch utilizations and the next trends of QQ-based biofouling control procedures for MBR [51] [90].

In the same context, Huang et al. [91] presented an exhaustive review on acyl-homoserine lactone (AHL)-based QS and QQ for increasing the efficiency of biological wastewater treatments. Shi et al. [36] focused on EPSs controlling procedures (QS systems) for effectiveness amelioration of biological wastewater treatments. Lin et al. [92] examined the EPSs properties and roles in membrane fouling and control procedures. Meng et al. [8] suggested an exhaustive and updated review on the fouling in MBRs. Lee et al. [93] focused on the opportunities and dares for biofouling control related to the QS and QQ in MBRs.

\section{Ultrasonic Technique for Coping with Membrane Fouling}

As seen above, membrane cleaning procedures could be mostly categorized into four classes comprising chemical, physical, physicochemical, and biological. Lately, ultrasonication has been discovered as an encouraging cleaning method for the MBRs membranes [94]. Indeed, ultrasonic irradiation could clean the fouled membrane by generating interesting physical processes involving micro-jets, micro-streams, and shock waves. In addition, ultrasonic technology can be integrated with different cleaning processes such as chemical cleaning and backwashing with a view to ameliorating the cleaning performance. In fact, implementing ultrasonic in the MBR system is not restricted to membrane cleaning. This is due to the fact that pretreating wastewater by ultrasonic irradiation or ultrasound merged with additional technologies (like ozonation) before the MBR setup has the potential to reduce the organic matter of the wastewater and then delay the membrane fouling. Arefi-Oskoui et al. [94] discussed the fresh signs of progress in utilizing ultrasound in MBR devices.

The particles could be liberated from the fouled membrane by the mentioned 
physical processes and/or by forming hydroxyl radicals in a heterogeneous liquid-solid system [94]. Applying ultrasonic could be realized either in-situ (online) or ex-situ (offline) for cleaning the membrane in the MBR setups. Implementing on-line ultrasonic irradiation could efficaciously dominate the membrane fouling in the MBR devices by dominating the production of the cake film on the membrane surface. Most of the investigations concerned the utilization of ultrasonic techniques in MBR setups on a laboratory scale. As a result, more attention stays requested to follow the ultrasound implementation on an industrial level focusing on the expansion of technical-economical techniques with low energy consumption.

\section{Surface Grafting Procedures for Dealing with Membrane Fouling}

Surface grafting procedures have a crucial contribution in enhancing the traditional membrane setup which is mainly hydrophobic in nature [95] [96]. The hydrophobic nature of membranes is recognized to provoke fouling, leading to increased maintenance costs and shorter lifetime of MBR. Therefore, surface grafting intends to ameliorate the hydrophilicity of bio-based membrane setups. Lee et al. [97] revised the main surface modification methods presently utilized in membranes, comprising photo-induced grafting, plasma treatment and plasma-induced grafting, radiation-induced grafting, thermal-induced grafting, and ozone-induced grafting. The fouling trouble can be settled with the surface grafting methods to reach better effectiveness of MBRs.

\section{Conclusions}

In this work, modern signs of progress in terms of membrane fouling control and novel configurations in MBRs are discussed. Employed for biofouling control, the QQ technique is briefly introduced. As a clean method used for coping with membrane fouling, the ultrasonic technique is shortly discussed. Finally, surface grafting techniques for dealing with membrane fouling are also suggested. From this work, the following conclusions can be drawn:

1) MBR fouling troubles have drawn the interest of researchers, practitioners, and MBR suppliers, and have conducted to diverse fouling-mitigation options, optimization procedures, and fresh commercial products. Such ameliorations focused on the module arrangement, aeration procedures, control setups, surface amendments, low-energy membrane cleaning techniques, or new fouling mitigation procedures, for instance, mechanical cleaning with granular medium [98], membrane vibration, or electric field. Numerous new MBR arrangements have been suggested to ameliorate membrane fouling control. Between such ameliorations, hybrid setups, merging MBR with different techniques, employing prospects of the diverse methods to get the better of regular limitations of the MBRs were the most important [1] [99].

2) More research is requested to find the best design and materials of QQ-media 
with a view to improving QQ activity and to decrease the price of QQ-MBR. Further, it is suggested to present a novel flat-sheet or hollow-fiber membrane modules in which part of sheets or fibers are substituted by QQ-sheets or QQ-fibers, respectively. Such QQ-membrane modules are anticipated to avoid a method for the separation of QQ-media from AS in QQ-MBR. Over the QQ-MBR, the capacity of QQ-technology can be extended to additional membrane techniques in water treatment for biofouling control, like anaerobic MBR (AnMBR) [100] [101] [102], reverse osmosis (RO), forward osmosis (FO) [103], FO-MBR [60], bioelectrochemical systems, BES-AnMBRs [104] [105], thermophilic membrane bioreactors (ThMBRs) [106], etc. [107] [108]. Indeed, the capability of QQ-AnMBR and QQ-RO has previously been established in lab-scale tests [51].

3) Even with unceasing enhancements and expansions, fouling control features remain to be fully met. Between the fouling control features, the expansion of original antifouling membranes, stable flux production for long term operation, efficient and/or low-energy membrane cleaning techniques and identification of tailored pretreatment protocols for alleviating the fouling issue stay required [1]. Fresh techniques were successfully employed to deal with the issue of membrane fouling in MBRs, such as nanomaterials, cell entrapment, biological concepts, and electrically-based processes. Nonetheless, implementing such novel fouling alleviation procedures for large scale MBRs needs more study. Sustainable control of membrane fouling necessitates utilizing more than one single strategy [109].

\section{Acknowledgements}

This research has been funded by the Research Deanship of University of Ha'il, Saudi Arabia, through the Project RG-191190.

\section{Conflicts of Interest}

The author declares no conflicts of interest regarding the publication of this paper.

\section{References}

[1] Krzeminski, P., Leverette, L., Malamis, S. and Katsou, E. (2017) Membrane Bioreactors-A Review on Recent Developments in Energy Reduction, Fouling Control, Novel Configurations, LCA and Market Prospects. Journal of Membrane Science, 527, 207-227. https://doi.org/10.1016/j.memsci.2016.12.010

[2] Zhang, J., Xiao, K. and Huang, X. (2020) Full-Scale MBR Applications for Leachate Treatment in China: Practical, Technical, and Economic Features. Journal of Hazardous Materials, 389, Article ID: 122138. https://doi.org/10.1016/j.jhazmat.2020.122138

[3] Couto, C.F., Lange, L.C. and Amaral, M.C.S. (2018) A Critical Review on Membrane Separation Processes Applied to Remove Pharmaceutically Active Compounds from Water and Wastewater. Journal of Water Process Engineering, 26, 
156-175. https://doi.org/10.1016/j.jwpe.2018.10.010

[4] Robles, Á., Ruano, M.V., Charfi, A., Lesage, G., Heran, M., Harmand, J., Seco, A., Steyer, J.-P., Batstone, D.J., Kim, J. and Ferrer, J. (2018) A Review on Anaerobic Membrane Bioreactors (AnMBRs) Focused on Modelling and Control Aspects. Bioresource Technology, 270, 612-626. https://doi.org/10.1016/j.biortech.2018.09.049

[5] Aslam, M., Ahmad, R., Yasin, M., Khan, A.L., Shahid, M.K., Hossain, S., Khan, Z., Jamil, F., Rafiq, S., Bilad, M.R., Kim, J. and Kumar, G. (2018) Anaerobic Membrane Bioreactors for Biohydrogen Production: Recent Developments, Challenges and Perspectives. Bioresource Technology, 269, 452-464.

https://doi.org/10.1016/j.biortech.2018.08.050

[6] Drews, A. (2010) Membrane Fouling in Membrane Bioreactors-Characterisation, Contradictions, Cause and Cures. Journal of Membrane Science, 363, 1-28. https://doi.org/10.1016/j.memsci.2010.06.046

[7] Meng, F., Chae, S.-R., Shin, H.-S., Yang, F. and Zhou, Z. (2011) Recent Advances in Membrane Bioreactors: Configuration Development, Pollutant Elimination, and Sludge Reduction. Environmental Engineering Science, 29, 139-160. https://doi.org/10.1089/ees.2010.0420

[8] Meng, F., Zhang, S., Oh, Y., Zhou, Z., Shin, H.-S. and Chae, S.-R. (2017) Fouling in Membrane Bioreactors: An Updated Review. Water Research, 114, 151-180. https://doi.org/10.1016/j.watres.2017.02.006

[9] Fenu, A., Guglielmi, G., Jimenez, J., Spèrandio, M., Saroj, D., Lesjean, B., Brepols, C., Thoeye, C. and Nopens, I. (2010) Activated Sludge Model (ASM) Based Modelling of Membrane Bioreactor (MBR) Processes: A Critical Review with Special Regard to MBR Specificities. Water Research, 44, 4272-4294. https://doi.org/10.1016/j.watres.2010.06.007

[10] Naessens, W., Maere, T. and Nopens, I. (2012) Critical Review of Membrane Bioreactor Models-Part 1: Biokinetic and Filtration Models. Bioresource Technology, 122, 95-106. https://doi.org/10.1016/j.biortech.2012.05.070

[11] Naessens, W., Maere, T., Ratkovich, N., Vedantam, S. and Nopens, I. (2012) Critical Review of Membrane Bioreactor Models-Part 2: Hydrodynamic and Integrated Models. Bioresource Technology, 122, 107-118. https://doi.org/10.1016/j.biortech.2012.05.071

[12] Zuthi, M.F.R., Ngo, H.H., Guo, W.S., Zhang, J. and Liang, S. (2013) A Review towards Finding a Simplified Approach for Modelling the Kinetics of the Soluble Microbial Products (SMP) in an Integrated Mathematical Model of Membrane Bioreactor (MBR). International Biodeterioration \& Biodegradation, 85, 466-473. https://doi.org/10.1016/j.ibiod.2013.03.032

[13] Bagheri, M., Akbari, A. and Mirbagheri, S.A. (2019) Advanced Control of Membrane Fouling in Filtration Systems Using Artificial Intelligence and Machine Learning Techniques: A Critical Review. Process Safety and Environmental Protection, 123, 229-252. https://doi.org/10.1016/j.psep.2019.01.013

[14] Ozgun, H., Dereli, R.K., Ersahin, M.E., Kinaci, C., Spanjers, H. and van Lier, J.B. (2013) A Review of Anaerobic Membrane Bioreactors for Municipal Wastewater Treatment: Integration Options, Limitations and Expectations. Separation and Purification Technology, 118, 89-104. https://doi.org/10.1016/j.seppur.2013.06.036

[15] Wang, Z., Ma, J., Tang, C.Y., Kimura, K., Wang, Q. and Han, X. (2014) Membrane Cleaning in Membrane Bioreactors: A review. Journal of Membrane Science, 468, 
276-307. https://doi.org/10.1016/j.memsci.2014.05.060

[16] Skouteris, G., Saroj, D., Melidis, P., Hai, F.I. and Ouki, S. (2015) The Effect of Activated Carbon Addition on Membrane Bioreactor Processes for Wastewater Treatment and Reclamation-A Critical Review. Bioresource Technology, 185, 399-410. https://doi.org/10.1016/j.biortech.2015.03.010

[17] Le-Clech, P., Chen, V. and Fane, T.A.G. (2006) Fouling in Membrane Bioreactors Used in Wastewater Treatment. Journal of Membrane Science, 284, 17-53.

https://doi.org/10.1016/j.memsci.2006.08.019

[18] Yusuf, Z., Abdul Wahab, N. and Sahlan, S. (2016) Fouling Control Strategy for Submerged Membrane Bioreactor Filtration Processes Using Aeration Airflow, Backwash, and Relaxation: A Review. Desalination and Water Treatment, 57, 17683-17695. https://doi.org/10.1080/19443994.2015.1086893

[19] Scholes, E., Verheyen, V. and Brook-Carter, P. (2016) A Review of Practical Tools for Rapid Monitoring of Membrane Bioreactors. Water Research, 102, 252-262. https://doi.org/10.1016/j.watres.2016.06.031

[20] Holloway, R.W., Achilli, A. and Cath, T.Y. (2015) The Osmotic Membrane Bioreactor: A Critical Review. Environmental Science: Water Research \& Technology, 1, 581-605. https://doi.org/10.1039/C5EW00103I

[21] Wang, X., Chang, V.W.C. and Tang, C.Y. (2016) Osmotic Membrane Bioreactor (OMBR) Technology for Wastewater Treatment and Reclamation: Advances, Challenges, and Prospects for the Future. Journal of Membrane Science, 504, 113-132. https://doi.org/10.1016/j.memsci.2016.01.010

[22] Song, X., Xie, M., Li, Y., Li, G. and Luo, W. (2018) Salinity Build-Up in Osmotic Membrane Bioreactors: Causes, Impacts, and Potential Cures. Bioresource Technology, 257, 301-310. https://doi.org/10.1016/j.biortech.2018.02.101

[23] Li, C., Cabassud, C. and Guigui, C. (2015) Evaluation of Membrane Bioreactor on Removal of Pharmaceutical Micropollutants: A Review. Desalination and Water Treatment, 55, 845-858. https://doi.org/10.1080/19443994.2014.926839

[24] Taheran, M., Brar, S.K., Verma, M., Surampalli, R.Y., Zhang, T.C. and Valero, J.R. (2016) Membrane Processes for Removal of Pharmaceutically Active Compounds (PhACs) from Water and Wastewaters. Science of the Total Environment, 547, 60-77. https://doi.org/10.1016/j.scitotenv.2015.12.139

[25] Gu, Y., Huang, J., Zeng, G., Shi, L., Shi, Y. and Yi, K. (2018) Fate of Pharmaceuticals during Membrane Bioreactor Treatment: Status and Perspectives. Bioresource Technology, 268, 733-748. https://doi.org/10.1016/j.biortech.2018.08.029

[26] Mutamim, N.S.A., Noor, Z.Z., Hassan, M.A.A. and Olsson, G. (2012) Application of Membrane Bioreactor Technology in Treating High Strength Industrial Wastewater: A Performance Review. Desalination, 305, 1-11. https://doi.org/10.1016/j.desal.2012.07.033

[27] Jegatheesan, V., Pramanik, B.K., Chen, J., Navaratna, D., Chang, C.-Y. and Shu, L. (2016) Treatment of Textile Wastewater with Membrane Bioreactor: A Critical Review. Bioresource Technology, 204, 202-212. https://doi.org/10.1016/j.biortech.2016.01.006

[28] Wu, B. (2019) Membrane-Based Technology in Greywater Reclamation: A Review. Science of the Total Environment, 656, 184-200. https://doi.org/10.1016/j.scitotenv.2018.11.347

[29] Ghernaout, D., Alshammari, Y., Alghamdi, A., Aichouni, M., Touahmia, M. and Ait 
Messaoudene, N. (2018) Water Reuse: Extenuating Membrane Fouling in Membrane Processes. International Journal of Environmental Chemistry, 2, 1-12. https://doi.org/10.11648/j.ijec.20180201.11

[30] Lin, H., Peng, W., Zhang, M., Chen, J., Hong, H. and Zhang, Y. (2013) A Review on Anaerobic Membrane Bioreactors: Applications, Membrane Fouling and Future Perspectives. Desalination, 314, 169-188. https://doi.org/10.1016/j.desal.2013.01.019

[31] Xiao, K., Liang, S., Wang, X., Chen, C. and Huang, X. (2019) Current State and Challenges of Full-Scale Membrane Bioreactor Applications: A Critical Review. Bioresource Technology, 271, 473-481. https://doi.org/10.1016/j.biortech.2018.09.061

[32] Song, X., Luo, W., Hai, F.I., Price, W.E., Guo, W., Ngo, H.H. and Nghiem, L.D. (2018) Resource Recovery from Wastewater by Anaerobic Membrane Bioreactors: Opportunities and Challenges. Bioresource Technology, 270, 669-677. https://doi.org/10.1016/j.biortech.2018.09.001

[33] Ait Messaoudene, N., Naceur, M.W., Ghernaout, D., Alghamdi, A. and Aichouni, M. (2018) On the Validation Perspectives of the Proposed Novel Dimensionless Fouling index. International Journal of Advances in Applied Sciences, 5, 116-122. https://doi.org/10.21833/ijaas.2018.07.014

[34] Metcalf, E., Ed. (2003) Wastewater Engineering: Treatment and Reuse. 4th Edition, McGraw-Hill Companies, Inc., New York.

[35] Meng, F., Chae, S.-R., Drews, A., Kraume, M., Shin, H.-S. and Yang, F. (2009) Recent Advances in Membrane Bioreactors (MBRs): Membrane Fouling and Membrane Material. Water Research, 43, 1489-1512.

https://doi.org/10.1016/j.watres.2008.12.044

[36] Shi, Y., Huang, J., Zeng, G., Gu, Y., Chen, Y., Hu, Y., Tang, B., Zhou, J., Yang, Y. and Shi, L. (2017) Exploiting Extracellular Polymeric Substances (EPS) Controlling Strategies for Performance Enhancement of Biological Wastewater Treatments: An Overview. Chemosphere, 180, 396-411. https://doi.org/10.1016/j.chemosphere.2017.04.042

[37] Judd, S.J. (2017) Membrane Technology Costs and Me. Water Research, 122, 1-9. https://doi.org/10.1016/j.watres.2017.05.027

[38] Judd, S. (2006) The MBR Book: Principles and Applications of Membrane Bioreactors in Water and Wastewater Treatment. Elsevier, Oxford.

[39] Aslam, M., Charfi, A., Lesage, G., Heran, M. and Kim, J. (2017) Membrane Bioreactors for Wastewater Treatment: A Review of Mechanical Cleaning by Scouring Agents to Control Membrane Fouling. Chemical Engineering Journal, 307, 897-913. https://doi.org/10.1016/j.cej.2016.08.144

[40] Lei, Z., Yang, S., Li, Y.-Y., Wen, W., Wang, X.C. and Chen, R. (2018) Application of Anaerobic Membrane Bioreactors to Municipal Wastewater Treatment at Ambient Temperature: A Review of Achievements, Challenges, and Perspectives. Bioresource Technology, 267, 756-768. https://doi.org/10.1016/j.biortech.2018.07.050

[41] Carstensen, F., Apel, A. and Wessling, M. (2012) In Situ Product Recovery: Submerged Membranes vs. External Loop Membranes. Journal of Membrane Science, 394-395, 1-36. https://doi.org/10.1016/j.memsci.2011.11.029

[42] Bérubé, P. (2010) Chap. 9. Membrane Bioreactors: Theory and Applications to Wastewater Reuse. In: Sustainability Science and Engineering, Vol. 2, Elsevier B.V., Amsterdam, 255-292. https://doi.org/10.1016/S1871-2711(09)00209-8

[43] Wu, J., Chen, F., Huang, X., Geng, W. and Wen, X. (2006) Using Inorganic Coagu- 
lants to Control Membrane Fouling in a Submerged Membrane Bioreactor. Desalination, 197, 124-136. https://doi.org/10.1016/j.desal.2005.11.026

[44] Lee, D.S., Jeon, C.O. and Park, J.M. (2001) Biological Nitrogen Removal with Enhanced Phosphate Uptake in a Sequencing Batch Reactor Using Single Sludge System. Water Research, 35, 3968-3976. https://doi.org/10.1016/S0043-1354(01)00132-4

[45] He, S.-B., Xue, G. and Kong, H.-N. (2006) Zeolite Powder Addition to Improve the Performance of Submerged Gravitation-Filtration Membrane Bioreactor. Journal of Environmental Sciences, 18, 242-247.

[46] Rezaei, M. and Mehrnia, M.R. (2014) The Influence of Zeolite (Clinoptilolite) on the Performance of a Hybrid Membrane Bioreactor. Bioresource Technology, 158, 25-31. https://doi.org/10.1016/j.biortech.2014.01.138

[47] Deng, L., Guo, W., Ngo, H.H., Zhang, J., Liang, S., Xia, S. and Zhang, Z. (2014) A Comparison Study on Membrane Fouling in a Sponge-Submerged Membrane Bioreactor and a Conventional Membrane Bioreactor. Bioresource Technology, 165, 69-74. https://doi.org/10.1016/j.biortech.2014.02.111

[48] Ng, H.Y., Tan, T.W. and Ong, S.L. (2006) Membrane Fouling of Submerged Membrane Bioreactors: Impact of Mean Cell Residence Time and the Contributing Factors. Environmental Science \& Technology, 40, 2706-2713. https://doi.org/10.1021/es0516155

[49] Deowan, S.A., Galiano, F., Hoinkis, J., Johnson, D., Altinkaya, S.A., Gabriel, B., Hilal, N., Drioli, E. and Figoli, A. (2016) Novel Low-Fouling Membrane Bioreactor (MBR) for Industrial Wastewater Treatment. Journal of Membrane Science, 510, 524-532. https://doi.org/10.1016/j.memsci.2016.03.002

[50] Zhao, C., Xu, X., Chen, J., Wang, G. and Yang, F. (2014) Highly Effective Antifouling Performance of PVDF/Graphene Oxide Composite Membrane in Membrane Bioreactor (MBR) System. Desalination, 340, 59-66. https://doi.org/10.1016/j.desal.2014.02.022

[51] Oh, H.-S. and Lee, C.-H. (2018) Origin and Evolution of Quorum Quenching Technology for Biofouling Control in MBRs for Wastewater Treatment. Journal of Membrane Science, 554, 331-345. https://doi.org/10.1016/j.memsci.2018.03.019

[52] Chang, H.N. (1987) Membrane Bioreactors: Engineering Aspects. Biotechnology Advances, 5, 129-145. https://doi.org/10.1016/0734-9750(87)90007-3

[53] Alizadeh Fard, M., Aminzadeh, B., Taheri, M., Farhadi, S. and Maghsoodi, M. (2013) MBR Excess Sludge Reduction by Combination of Electrocoagulation and Fenton Oxidation Processes. Separation and Purification Technology, 120, 378-385. https://doi.org/10.1016/j.seppur.2013.10.012

[54] Keerthi, Vinduja, V. and Balasubramanian, N. (2013) Electrocoagulation-Integrated Hybrid Membrane Processes for the Treatment of Tannery Wastewater. Environmental Science and Pollution Research, 20, 7441-7449. https://doi.org/10.1007/s11356-013-1766-y

[55] Neoh, C.H., Noor, Z.Z., Mutamim, N.S.A. and Lim, C.K. (2016) Green Technology in Wastewater Treatment Technologies: Integration of Membrane Bioreactor with Various Wastewater Treatment Systems. Chemical Engineering Journal, 283, 582-594. https://doi.org/10.1016/j.cej.2015.07.060

[56] Ma, J., Dai, R., Chen, M., Khan, S.J. and Wang, Z. (2018) Applications of Membrane Bioreactors for Water Reclamation: Micropollutant Removal, Mechanisms and Perspectives. Bioresource Technology, 269, 532-543.

https://doi.org/10.1016/j.biortech.2018.08.121 
[57] Tian, Y., Li, H., Li, L., Su, X., Lu, Y., Zuo, W. and Zhang, J. (2016) In-Situ Integration of Microbial Fuel Cell with Hollow-Fiber Membrane Bioreactor for Wastewater Treatment and Membrane Fouling Mitigation. Biosensors \& Bioelectronics, 64, 189-195. https://doi.org/10.1016/j.bios.2014.08.070

[58] Shin, C. and Bae, J. (2018) Current Status of the Pilot-Scale Anaerobic Membrane Bioreactor Treatments of Domestic Wastewaters: A Critical Review. Bioresource Technology, 247, 1038-1046. https://doi.org/10.1016/j.biortech.2017.09.002

[59] Besha, A.T., Gebreyohannes, A.Y., Tufa, R.A., Bekele, D.N., Curcio, E. and Giorno, L. (2017) Removal of Emerging Micropollutants by Activated Sludge Process and Membrane Bioreactors and the Effects of Micropollutants on Membrane Fouling: A Review. Journal of Environmental Chemical Engineering, 5, 2395-2414. https://doi.org/10.1016/j.jece.2017.04.027

[60] Qin, L., Zhang, Y., Xu, Z. and Zhang, G. (2018) Advanced Membrane Bioreactors Systems: New Materials and Hybrid Process Design. Bioresource Technology, 269, 476-488. https://doi.org/10.1016/j.biortech.2018.08.062

[61] Wu, G., Cui, L. and Xu, Y. (2008) A Novel Submerged Rotating Membrane Bioreactor and Reversible Membrane Fouling Control. Desalination, 228, 255-262. https://doi.org/10.1016/j.desal.2007.10.014

[62] Zuo, D.-Y., Li, H.-J., Liu, H.-T. and Wu, G.-P. (2010) A Study on Submerged Rotating MBR for Wastewater Treatment and Membrane Cleaning. Korean Journal of Chemical Engineering, 27, 881-885. https://doi.org/10.1007/s11814-010-0123-9

[63] Jiang, T., Zhang, H., Yang, F., Gao, D. and Du, H. (2013) Relationships between Mechanically Induced Hydrodynamics and Membrane Fouling in a Novel Rotating Membrane Bioreactor. Desalination and Water Treatment, 51, 2850-2861. https://doi.org/10.1080/19443994.2012.750794

[64] Jiang, T., Zhang, H., Gao, D., Dong, F., Gao, J. and Yang, F. (2012) Fouling Characteristics of a Novel Rotating Tubular Membrane Bioreactor. Chemical Engineering and Processing: Process Intensification, 62, 39-46.

https://doi.org/10.1016/j.cep.2012.09.012

[65] Rector, T.J., Garland, J.L. and Starr, S.O. (2006) Dispersion Characteristics of a Rotating Hollow Fiber Membrane Bioreactor: Effects of Module Packing Density and Rotational Frequency. Journal of Membrane Science, 278, 144-150. https://doi.org/10.1016/j.memsci.2005.10.050

[66] Liu, L., Gao, B., Liu, J. and Yang, F. (2012) Rotating a Helical Membrane for Turbulence Enhancement and Fouling Reduction. Chemical Engineering Journal, 181-182, 486-493. https://doi.org/10.1016/j.cej.2011.12.007

[67] Bentzen, T.R., Ratkovich, N., Madsen, S., Jensen, J.C., Bak, S.N. and Rasmussen, M.R. (2012) Analytical and Numerical Modelling of Newtonian and Non-Newtonian Liquid in a Rotational Cross-Flow MBR. Water Science and Technology, 66, 2318-2327. https://doi.org/10.2166/wst.2012.443

[68] Alnaizy, R., Aidan, A. and Luo, H. (2011) Performance Assessment of a Pilot-Size Vacuum Rotation Membrane Bioreactor Treating Urban Wastewater. Applied Water Science, 1, 103-110. https://doi.org/10.1007/s13201-011-0013-2

[69] Kola, A., Ye, Y., Ho, A., Le-Clech, P. and Chen, V. (2012) Application of Low Frequency Transverse Vibration on Fouling Limitation in Submerged Hollow Fibre Membranes. Journal of Membrane Science, 409-410, 54-65. https://doi.org/10.1016/j.memsci.2012.03.017

[70] Li, T., Law, A.W.-K., Cetin, M. and Fane, A.G. (2013) Fouling Control of Sub- 
merged Hollow Fibre Membranes by Vibrations. Journal of Membrane Science, 427, 230-239. https://doi.org/10.1016/j.memsci.2012.09.031

[71] Bilad, M.R., Mezohegyi, G., Declerck, P. and Vankelecom, I.F.J. (2012) Novel Magnetically Induced Membrane Vibration (MMV) for Fouling Control in Membrane Bioreactors. Water Research, 46, 63-72. https://doi.org/10.1016/j.watres.2011.10.026

[72] Ho, J., Smith, S. and Roh, H.K. (2014) Alternative Energy Efficient Membrane Bioreactor Using Reciprocating Submerged Membrane. Water Science and Technology, 70, 1998-2003. https://doi.org/10.2166/wst.2014.447

[73] Low, S.C., Cheong, K.T. and Lim, H.L. (2009) A Vibration Membrane Bioreactor. Desalination and Water Treatment, 5, 42-47. https://doi.org/10.5004/dwt.2009.563

[74] Altaee, A., Al-Rawajfeh, A.E. and Baek, Y.J. (2009) Application of Vibratory System to Improve the Critical Flux in Submerged Hollow Fiber MF Process. Separation Science and Technology, 45, 28-34. https://doi.org/10.1080/01496390903401796

[75] Maaz, M., Yasin, M., Aslam, M., Kumar, G., Atabani, A.E., Idrees, M., Anjum, F., Jamil, F., Ahmad, R., Khan, A.L., Lesage, G., Heran, M. and Kim, J. (2019) Anaerobic Membrane Bioreactors for Wastewater Treatment: Novel Configurations, Fouling Control and Energy Considerations. Bioresource Technology, 283, 358-372. https://doi.org/10.1016/j.biortech.2019.03.061

[76] Liu, L., Xu, X., Zhao, C. and Yang, F. (2010) A New Helical Membrane Module for Increasing Permeate Flux. Journal of Membrane Science, 360, 142-148. https://doi.org/10.1016/j.memsci.2010.05.014

[77] Jie, L., Liu, L., Yang, F., Liu, F. and Liu, Z. (2012) The Configuration and Application of Helical Membrane Modules in MBR. Journal of Membrane Science, 392-393, 112-121. https://doi.org/10.1016/j.memsci.2011.12.011

[78] Pentair's Helix Membranes. https://xflow.pentair.com/en/products/compact-helix

[79] Kimura, K. and Watanabe, Y. (2005) Baffled Membrane Bioreactor (BMBR) for Advanced Wastewater Treatment: Easy Modification of Existing MBRs for Efficient Nutrient Removal. Water Science and Technology, 52, 427-434. https://doi.org/10.2166/wst.2005.0720

[80] Kimura, K., Nishisako, R., Miyoshi, T., Shimada, R. and Watanabe, Y. (2008) Baffled Membrane Bioreactor (BMBR) for Efficient Nutrient Removal from Municipal Wastewater. Water Research, 42, 625-632. https://doi.org/10.1016/j.watres.2007.08.012

[81] Yan, X., Xiao, K., Liang, S., Lei, T., Liang, P., Xue, T., Yu, K., Guan, J. and Huang, X. (2015) Hydraulic Optimization of Membrane Bioreactor via Baffle Modification Using Computational Fluid Dynamics. Bioresource Technology, 175, 633-637. https://doi.org/10.1016/j.biortech.2014.10.133

[82] Shariati, F.P., Mehrnia, M.R., Sarrafzadeh, M.H., Rezaee, S., Grasmick, A. and Heran, M. (2013) Fouling in a Novel Airlift Oxidation Ditch Membrane Bioreactor (AOXMBR) at Different High Organic Loading Rate. Separation and Purification Technology, 105, 69-78. https://doi.org/10.1016/j.seppur.2012.12.008

[83] Kurita, T., Kimura, K. and Watanabe, Y. (2015) Energy Saving in the Operation of Submerged MBRs by the Insertion of Baffles and the Introduction of Granular Materials. Separation and Purification Technology, 141, 207-213.

https://doi.org/10.1016/j.seppur.2014.11.025

[84] Komesli, O.T. and Gökçay, C.F. (2013) Investigation of Sludge Viscosity and Its Effects on the Performance of a Vacuum Rotation Membrane Bioreactor. Environ- 
mental Technology, 35, 645-652. https://doi.org/10.1080/09593330.2013.840655

[85] Deng, L., Guo, W., Ngo, H.H., Zhang, H., Wang, J., Li, J., Xia, S. and Wu, Y. (2016) Biofouling and Control Approaches in Membrane Bioreactors. Bioresource Technology, 221, 656-665. https://doi.org/10.1016/j.biortech.2016.09.105

[86] Abuabdou, S.M.A., Ahmad, W., Aun, N.C. and Bashir, M.J.K. (2020) A Review of Anaerobic Membrane Bioreactors (AnMBR) for the Treatment of Highly Contaminated Landfill Leachate and Biogas Production: Effectiveness, Limitations and Future Perspectives. Journal of Cleaner Production, 255, Article ID: 120215. https://doi.org/10.1016/j.jclepro.2020.120215

[87] Nunes, S.P. (2016) Block Copolymer Membranes for Aqueous Solution Applications. Macromolecules, 49, 2905-2916. https://doi.org/10.1021/acs.macromol.5b02579

[88] Yeon, K.M., Cheong, W.S., Oh, H.S., Lee, W.N., Hwang, B.K., Lee, C.H., Beyenal, H. and Lewandowski, Z. (2009) Quorum Sensing: A New Biofouling Control Paradigm in a Membrane Bioreactor for Advanced Wastewater Treatment. Environmental Science \& Technology, 43, 380-385. https://doi.org/10.1021/es8019275

[89] Aslam, M., Ahmad, R. and Kim, J. (2018) Recent Developments in Biofouling Control in Membrane Bioreactors for Domestic Wastewater Treatment. Separation and Purification Technology, 206, 297-315. https://doi.org/10.1016/j.seppur.2018.06.004

[90] Nguyen, L.N., Commault, A.S., Kahlke, T., Ralph, P.J., Semblante, G.U., Johir, M.A.H. and Nghiem, L.D. (2020) Genome Sequencing as a New Window into the Microbial Community of Membrane Bioreactors-A Critical Review. Science of the Total Environment, 704, Article ID: 135279. https://doi.org/10.1016/j.scitotenv.2019.135279

[91] Huang, J., Shi, Y., Zeng, G., Gu, Y., Chen, G., Shi, L., Hu, Y., Tang, B. and Zhou, J. (2016) Acyl-Homoserine Lactone-Based Quorum Sensing and Quorum Quenching Hold Promise to Determine the Performance of Biological Wastewater Treatments: An Overview. Chemosphere, 157, 137-151. https://doi.org/10.1016/j.chemosphere.2016.05.032

[92] Lin, H., Zhang, M., Wang, F., Meng, F., Liao, B.-Q., Hong, H., Chen, J. and Gao, W. (2014) A Critical Review of Extracellular Polymeric Substances (EPSs) in Membrane Bioreactors: Characteristics, Roles in Membrane Fouling and Control Strategies. Journal of Membrane Science, 460, 110-125. https://doi.org/10.1016/j.memsci.2014.02.034

[93] Lee, K., Yu, H., Zhang, X. and Choo, K.-H. (2018) Quorum Sensing and Quenching in Membrane Bioreactors: Opportunities and Challenges for Biofouling Control. Bioresource Technology, 270, 656-668. https://doi.org/10.1016/j.biortech.2018.09.019

[94] Arefi-Oskoui, S., Khataee, A., Safarpour, M., Orooji, Y. and Vatanpour, V. (2019) A Review on the Applications of Ultrasonic Technology in Membrane Bioreactors. Ultrasonics Sonochemistry, 58, Article ID: 104633. https://doi.org/10.1016/j.ultsonch.2019.104633

[95] Ghernaout, D., El-Wakil, A., Alghamdi, A., Elboughdiri, N. and Mahjoubi, A. (2018) Membrane Post-Synthesis Modifications and How It Came about. International Journal of Advances in Applied Sciences, 5, 60-64. https://doi.org/10.21833/ijaas.2018.02.010

[96] Ghernaout, D. and El-Wakil, A. (2017) Requiring Reverse Osmosis Membranes Modifications-An Overview. American Journal of Chemical Engineering, 5, 81-88. 
https://doi.org/10.11648/j.ajche.20170504.15

[97] Lee, X.J., Show, P.L., Katsuda, T., Chen, W.-H. and Chang, J.-S. (2018) Surface Grafting Techniques on the Improvement of Membrane Bioreactor: State-of-the-Art Advances. Bioresource Technology, 269, 489-502. https://doi.org/10.1016/j.biortech.2018.08.090

[98] Iorhemen, O.T., Hamza, R.A. and Tay, J.H. (2017) Membrane Fouling Control in Membrane Bioreactors (MBRs) Using Granular Materials. Bioresource Technology, 240, 9-24. https://doi.org/10.1016/j.biortech.2017.03.005

[99] Yan, T., Ye, Y., Ma, H., Zhang, Y., Guo, W., Du, B., Wei, Q., Wei, D. and Ngo, H.H. (2018) A Critical Review on Membrane Hybrid System for Nutrient Recovery from Wastewater. Chemical Engineering Journal, 348, 143-156. https://doi.org/10.1016/j.cej.2018.04.166

[100] Stazi, V. and Tomei, M.C. (2018) Enhancing Anaerobic Treatment of Domestic Wastewater: State of the Art, Innovative Technologies and Future Perspectives. Science of the Total Environment, 635, 78-91. https://doi.org/10.1016/j.scitotenv.2018.04.071

[101] Bakonyi, P., Nemestóthy, N., Simon, V. and Bélafi-Bakó, K. (2014) Fermentative Hydrogen Production in Anaerobic Membrane Bioreactors: A Review. Bioresource Technology, 156, 357-363. https://doi.org/10.1016/j.biortech.2014.01.079

[102] Hu, Y., Wang, X.C., Ngo, H.H., Sun, Q. and Yang, Y. (2018) Anaerobic Dynamic Membrane Bioreactor (AnDMBR) for Wastewater Treatment: A Review. Bioresource Technology, 247, 1107-1118. https://doi.org/10.1016/j.biortech.2017.09.101

[103] Lee, D.-J. and Hsieh, M.-H. (2019) Forward Osmosis Membrane Processes for Wastewater Bioremediation: Research Needs. Bioresource Technology, 290, Article ID: 121795. https://doi.org/10.1016/j.biortech.2019.121795

[104] Cheng, D., Ngo, H.H., Guo, W., Liu, Y., Chang, S.W., Nguyen, D.D., Nghiem, L.D., Zhou, J. and Ni, B. (2018) Anaerobic Membrane Bioreactors for Antibiotic Wastewater Treatment: Performance and Membrane Fouling Issues. Bioresource Technology, 267, 714-724. https://doi.org/10.1016/j.biortech.2018.07.133

[105] Zhen, G., Pan, Y., Lu, X., Li, Y.-Y., Zhang, Z., Niu, C., Kumar, G., Kobayashi, T., Zhao, Y. and Xu, K. (2019) Anaerobic Membrane Bioreactor towards Biowaste Biorefinery and Chemical Energy Harvest: Recent Progress, Membrane Fouling and Future Perspectives. Renewable \& Sustainable Energy Reviews, 115, Article ID: 109392. https://doi.org/10.1016/j.rser.2019.109392

[106] Duncan, J., Bokhary, A., Fatehi, P., Kong, F., Lin, H. and Liao, B. (2017) Thermophilic Membrane Bioreactors: A Review. Bioresource Technology, 243, 1180-1193. https://doi.org/10.1016/j.biortech.2017.07.059

[107] Mahboubi, A., Ylitervo, P., Doye, W., De Wever, H. and Taherzadeh, M.J. (2016) Reverse Membrane Bioreactor: Introduction to a New Technology for Biofuel Production. Biotechnology Advances, 34, 954-975.

https://doi.org/10.1016/j.biotechadv.2016.05.009

[108] Viet, N.D., Cho, J., Yoon, Y. and Jang, A. (2019) Enhancing the Removal Efficiency of Osmotic Membrane Bioreactors: A Comprehensive Review of Influencing Parameters and Hybrid Configurations. Chemosphere, 236, Article ID: 124363. https://doi.org/10.1016/j.chemosphere.2019.124363

[109] Bagheri, M. and Mirbagheri, S.A. (2018) Critical Review of Fouling Mitigation Strategies in Membrane Bioreactors Treating Water and Wastewater. Bioresource Technology, 258, 318-334. https://doi.org/10.1016/j.biortech.2018.03.026 